\title{
Rhodometra sacraria (Linnaeus), a cosmopolitan sterrhine confirmed from Chile (Lepidoptera, Geometridae)
}

\author{
Gareth Edward King \& José Luis Viejo Montesinos
}

\author{
Departamento de Biología (Zoología), Universidad Autónoma de Madrid, C/. Darwin, 2, 28049 Cantoblanco (Madrid), Spain. \\ sterrhinae@gmail.com; joseluis.viejo@uam.es
}

\begin{abstract}
Rhodometra sacraria (Linnaeus), a cosmopolitan sterrhine confirmed from Chile (Lepidoptera, Geometridae). Rhodometra sacraria (Linnaeus, 1767), corologically a cosmopolitan species, is documented from Chile thanks to the analysis of specimens from four different localities in that country, at the same time, increasing the number of species known from the subfamily Sterrhinae in Chile, as well as being only the second (confirmed) documentation of this species from the Neotropics.
\end{abstract}

KEY WORDS: Chile; Insecta; Rhodometra; Sterrhinae.

According to Parra (1995), 450 species are documented from Chile in the family Geometridae. With reference to the subfamily Sterrhinae, there are only eight species present: Scopula umbilicata (Fabricius, 1784) (Vargas \& Hausmann 2008); Rhodostrophia cauquenensis (Butler, 1882), $R$. chilenaria (Blanchard, 1852) and R. ferruginaria (Blanchard, 1852) (Trusch \& Hausmann 2008); Cyclophora nanaria (Walker, 1861), C. semirosea (Butler, 1882) and C. umbrata (Butler, 1881) (Vargas et al. 2001; Angulo \& Casanueva, 1981), in addition to Cyllopoda claudicula (Dalman, 1823) (Lewis \& Covell 2008).

The genus Rhodometra Meyrick, 1892 is centred on the Afrotropical region (eight species), with two species being known from the Neotropical Region, these being: Rhodometra angasmarcata (Dognin, 1917) from Peru, and $R$. virgenpamba (Dognin, 1892) which flies in Ecuador. Rhodometra sacraria (Linnaeus, 1767) is the only representative in the Palearctic (Scoble 1999; Hausmann 2004), at the same time being an important migrant or divagant ( $r$-strategy) (Skule 1980; Skule \& Svendsen 1980), whose biology contrasts with those species in the genus Casilda Agenjo, 1952, which also belong to the tribe Rhodometrini Agenjo, 1952, these being stenotypic taxa ( $k$ - strategy) (Hausmann 2004).

Rhodometra sacraria is corologically a cosmopolitan species with an important distributional focus on the Mediterranean Basin (Hausmann 1994; Parenzan 1998), but migrates great distances reaching northern Europe countries such as Scotland and Norway (Skule \& Svendsen 1984; Grosser \& Meier 1986; Johanson 1993). It is also to be found in Macaronesia, for example, the Canary Islands (throughout the archipelago) (Bacallado et al. 2006); Hausmann (2004) also documents it from Madeira and the Azores; Prout (1935) cites it from tropical and Austral Africa; in Asia it reaches SE China and eastern Mongolia, being also found across India (Viidalepp 1996; Häuser 2001). Hausmann (2004) included a possible documentation of this species from El
Salvador; in this present paper we provide data on this specimen confirming its presence in the Neotropics.

In certain Spanish and Portuguese regions. Rhodometra sacraria is to be taken in almost all months of the year (Monteiro \& Passos De Carvalho 1984; Corley et al. 2000; Novoa Peréz et al. 2002; Corley 2004) with larvae being found in the colder months of at least November and December (King 1997; also unpublished data from Madrid, Spain), without the larval stage being quiescent as such, although it does survive low temperatures in captivity (as does the pupa) $\left(\hat{\mathrm{A}} 6^{\circ} \mathrm{C}\right.$; unpublished data from Madrid, GEK). It is an oligophagous species on Polygonaceae, these plants can be regarded as pioneers in open soils, which at times can form dense mats: Polygonum aviculare L., for example, underneath which can be found the rapidly-developing larvae (Gómez de Aizpúrua et al. 2006; unpublished data from Madrid, 2006-2013).

\section{MATERIAL AND METHODS}

The material studied belongs to the following collections: GEK, personal collection of Gareth King, Madrid (Spain); MNCN, Museo Nacional de Ciencias Naturales, Madrid (Spain); UAM, Universidad Autónoma de Madrid; ZSM, Zoologische Staatssamlung Munich (Germany). Genital preparations were made according to standard techniques (Robinson 1976). Only one genital preparation was made of the three specimens analysed from the collection at the Universidad de Concepción, due to apparent loss in the February 2010 earthquake (Luis Parra, pers. comm.). This male specimen (details below) was compared with extensive material from Madrid (UAM; GEK).

\section{RESULTS AND DISCUSSION}

The geometrid collection of the Zoology Department, Faculty of Natural \& Ocean Sciences, Universidad de 
Concepción, Chile, was inspected, paying special attention to three examples in the genus Rhodometra which were found in a batch of specimens in the genus Perusia Herrich-Schäffer, 1855 (Ennominae). With this paper almost completed, another specimen of Rhodometra was received courtesy of the ZSM, Munich, Germany (Fig. 1). This latter specimen (detailed below) was bereft of abdomen, but DNA-barcoding within the BOLD TaxonID Tree Project, whereby ostensible $R$. sacraria material from Africa and Asia was examined and was also confirmed as belonging to this species (A. Hausmann, pers. comm., 3.viii.2011). In addition, we also received original data on the El Salvador specimen (A. Hausmann, pers. comm., 12.xi.2013).

Five specimens of Rhodometra sacraria are currently known from the New World, four from Chile and one from El Salvador. Data on these specimens is as follows:

EL SALVADOR: F San Salvador, 600m, 13.ix.1961, B. Bechymé leg. (gen. prep. ZSM G 11338 Axel Hausmann det); CHILE: F (Fig. 1) (Barcode $\mathrm{N}^{\circ}$ BC ZSM Lep 30365); 3.IV.1998, Petorca Qda., Aguas Claras, Valparaíso, 600m, H. Thoeny leg. et Axel Hausmann det.; M (code: ZA POO4) I. 2004, Penco (sea level) (Región de Biobío); F (ZM POO2), 3.II.2005, El Calor, Panguilemo, 102m, province Talca (Región de Maule); M (3710 Fig. 1); 20-27.IV.2005; Santa Fe, Los Ángeles, 139m (Región de Biobío) all specimens Luis Parra leg. et Gareth King det.

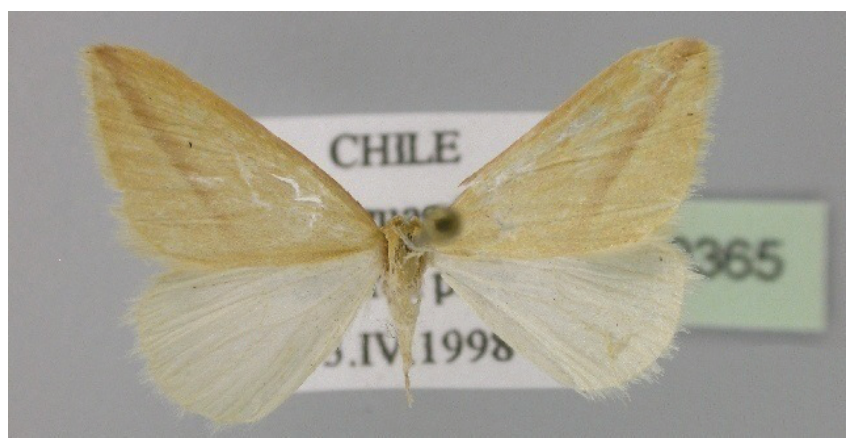

Fig. 1. Rhodometra sacraria, o (Barcode Nr. BC ZSM Lep 30365) 3.IV.1998, Petorca Qda., Aguas Claras, Valparaíso, 600m, CHILE, H. Thoeny leg. Axel Hausmann det.

With the finding of four specimens of Rhodometra sacraria from Chile the genus Rhodometra Meyrick, 1892 now has three species in the Neotropical Region, in addition, to being the first taxon documented for Chile in the Rhodometrini. This material which includes data both from the Chilean coast and from the Chilean interior at low altitude, in some way, reflects its distribution in the Mediterranean Basin, that is to say, it is not generally a high altitude species, a characteristic typical of the subfamily Sterrhinae (Brehm \& Fiedler 2003; Hausmann 2004). It also has to be said, that these new data are from sun exposed, open areas, anthropogenically influenced, with ruderal vegetation, which would be appropriate for the growth of polygonaceous plants (Gómez de Aizpúrua et al. 2006).

In this way, there are now nine species in the Sterrhinae recognised from Chile, forming $2 \%$ of the geometrid fauna.
In addition, amongst the Sterrhinae, $R$. sacraria is the second sterrhine taxon which has been taken in the centre-south of the country, and the only sterrhine species as far south as Biobío. For example, S. umbilicata was documented from Arica (extreme north just south of Peru) (Vargas \& Hausmann 2008), whilst, the three species in the genus Cyclophora Hübner, 1822, C. nanaria, C. semirosea and C. umbrata, are known either from the Azapa Valley (Arica), or from the Tamarugal Pampa (Iquique) (C. nanaria), or from Valparaíso (C. semirosea, C. umbrata) (Vargas et al. 2001). On the other hand, the subfamily Larentiinae is well represented in the meridional zones of Chile. For example, of the 87 geometrid species collected in a campaign of only a few days duration in Huinay (Región de Los Lagos), 53 species belonged to this subfamily (61\%) (Hausmann \& Parra 2009). There are no sterrhines documented from southern Chile (Angulo \& Casanueva 1981).

Rhodometra sacraria is an important migratory species with data available on its movements north-westwards from the Mediterranean Basin within Europe (Skule \& Svendsen 1984; Grosser \& Meier 1986; Johanson 1993; Sparks et al. 2007). In fact, Sparks et al. (2007) correlate increasing average temperatures in south-west Europe (data over 21 years) with the increasing likelihood of this sterrhine being recorded in southern England. In the European context, for example, in central Spain under a meso-Mediterranean climatic regime, the species cannot survive periods of sub-zero temperatures and/or prolonged rain, although the exact abiotic mechanisms at play are not sufficiently understood (GEK, unpublished data). In the tribe Rhodometrini the related species Casilda consecraria (Staudinger, 1871), which often flies alongside $R$. sacraria in those central Spanish areas where the two species are sympatric, is a stenotypic species overwintering as a pupa within a substantial cocoon (GEK, unpublished data) quite unlike that of $R$. sacraria (Skule 1980). The fact that the insect is unable to overwinter in the sense that it has a dormant stage (Leather et al. 1993) means that the moth has been recorded flying in the winter months in the Portuguese Algarve (Corley et al. 2000).

In the context of the taxon's migratory tendencies, the question needs to be addressed of how it came to be documented from El Salvador in 1961 and from Chile in 1998. The Central American geometrid fauna is poorly known with recent data from Costa Rica (Pitkin et al. 1996; Brehm \& Axmacher 2006, amongst others) and Nicaragua (Viidalepp, et al. 2010). As there is a gap of 37 years between the El Salvadorean and Chilean findings it would suggest that they are unrelated in origin, especially if one considers that an 'intermediate' country such as Ecuador is well studied in terms of its geometrid fauna (Brehm, et al. 2003; Brehm \& Fiedler 2003; Bodner et al. 2009; Strutzenberger et al. 2010, amongst others) (the observation that the subfamily Sterrhinae is not well-represented at high altitudes, in fact, used data from an Ecuadorian study (Brehm, et al. 2003; Brehm \& Fiedler 2003)). It needs to be considered if the 1998 specimen from Valparaíso (see above) was of Chinese ori- 
gin, given that the aforementioned locality is one of Chile's most important ports and that the species is documented from SE China (Häuser 2001), as well as the fact that this country is Chile's most important trading partner (Pérez Muñoz 2007). In addition, neither $R$. sacraria nor $R$. angasmarcata (about whose biology there is nothing known, but which may also be expected to demonstrate migratory tendencies) have been documented from those areas of northern Chile which may more likely be points of entry across valleys for those Neotropical species whose southern distributional limits incorporate northern Chile, for example, S. umbilicata (Covell, 1970) and Pero obtusaria Prout, 1928 (Ennominae) (Poole 1987). Both of these geometrids were very recently documented from Chile (Vargas \& Hausmann 2008).

Rhodometra sacraria can be regarded as being synanthropic with data from urban areas in Madrid both of larvae and of imagines (GEK, unpublished data) it taking advantage of pioneer ruderal vegetation (Sanz Alorza 2009). In the same way, $C$. nanaria also makes its presence felt in areas of anthropogenic influence in Chile, it being a minor pest of Olea europaea L. (Vargas et al. 2001).

\section{ACKNOWLEDGEMENTS}

We wish to thank most gratefully Luis Parra of the Zoology Department, Universidad de Concepción, Chile for the donation of material, without which this paper would have been impossible to have put together. In addition, we warmly thank Axel Hausmann of the Staatliche Naturwissenschaftliche Sammlungen Bayerns, Munich, Germany for the photograph of the first Chilean specimen and its corresponding data, as well as unpublished data on the Salvadorean specimen. The first-named author would also wish to mention the concession of a grant from the Research Section of the Universidad Autónoma de Madrid in 2010, the importance of which made possible the trip to Chile (Projects 541D708 and 541D731). Gratitude is also expressed to two anonymous reviewers for their helpful comments and suggestions in terms of how to improve on our initial manuscript.

\section{REFERENCES}

Angulo, A.O. \& Casanueva, M.E. 1981. Catálogo de los Lepidópteros Geométridos de Chile (Lepidoptera: Geometridae). Boletín de la Sociedad de Biología de Concepción 51: 7-39.

Bacallado, J.J., Hausmann, A., Moro, L. \& de Vera, A. 2006. La subfamilia Sterrhinae Meyrick, 1892 (Lepidoptera: Geometridae) en las Islas Canarias. Revista de la Academia Canaria de Ciencias 17: 73-102.

Bodner, F., Brehm, G., Homeier, J., Strutzenberger, P. \& Fiedler, F. 2009. Caterpillars and host plant records for 59 species of Geometridae (Lepidoptera) from a montane rainforest in southern Ecuador. Journal of Insect Science 10: 1-22.

Brehm, G. \& Fiedler, K. 2003. Faunal composition of geometrid moths changes with altitude in an Andean montane rain forest. Journal of Biogeography 30: 431-440.

Brehm, G., Homeier, J. \& Fiedler, K. 2003. Beta diversity of Geometrid moths in an Andean montane rainforest. Diversity and Distributions 9: $351-366$.
Brehm, G. \& Axmacher, J.C. 2006. A comparison of manual and automatic moth sampling methods (Lepidoptera: Arctiidae, Geometridae) in a rainforest in Costa Rica. Environmental Entomology 35: 754-764.

Corley, M.F.V. 2004. Provisional list of the Lepidoptera of Lagoa de Santo André, Baixo Alentejo, Portugal. (Insecta: Lepidoptera). SHILAP Revista de Lepidopterología 32: 105-138.

Corley, M.F.V, Gardiner, A.J., Cleere, N. \& Wallis, P.D. 2000. Further additions to the Lepidoptera of Algarve, Portugal (Insecta: Lepidoptera). SHILAP Revista de Lepidopterología 28: 245-319.

Gómez de Aizpúrua, C., González Granados, J. \& Viejo-Montesinos, J.L. 2006. Mariposas y sus biotopos, Reserva Natural El Regajal-mar de Ontígola, Lepidoptera III memoria 2004. Comunidad de Madrid, 299 p.

Grosser, N. \& Meier, G. 1986. Rhodometra sacraria (Linne, 1767) in der DDR (Lepidoptera, Geometridae). Atalanta 17: 147-149.

Hausmann, A. 1994. Beitrag zur Geometridenfauna Zyperns. Zeitschrift der Arbeitsgemeinschaft Österreichische Entomologen 46: 81-98.

Hausmann, A. 2004. Sterrhinae, p. 1-600. In: Hausmann, A. (ed.). The Geometrid Moths of Europe, 2. Stenstrup, Apollo Books.

Hausmann, A. \& Parra, L.E. 2009. An unexpected hotspot of moth diversity in Chilean northern Patagonia (Lepidoptera: Geometridae). Zootaxa 1989: $23-38$.

Häuser, C. 2001. Rhodometra sacraria (Linnaeus, 1767), p. 209-210. In: Ebert, G. (ed.). Die Schmetterlinge Baden-Wüttermbergs, Vol. 8, Nachfalter VI, Geometridae. Stuttgart, Verlag E. Ulmer, 541 p.

Johanson, K.A. 1993. Records of the migrant Rhodometra sacraria (Linnaeus, 1767) (Lepidoptera: Geometridae) in Norway. Fauna Norvegica, Serie B, 40: 46.

King, G.E. 1997. Homolobus truncator Say (Braconidae: Homolobinae) parasitoide de Rhodometra sacraria Linné (Geometridae: Sterrhinae) en Algarve, Portugal. Boletín de la Sociedad Entomológica de Aragón 18 (B): 66.

Leather, S.R., Walters, K.F.A. \& Bale, J.S. 1993. The Ecology of Insect Overwintering. Cambridge University Press, 255 p.

Lewis, D.S. \& Covell, C.V. 2008. A review of the neotropical genus Cyllopoda (Lepidoptera: Geometridae: Sterrhinae: Cyllopodini). Tropical Lepidoptera Research 18: 88-101.

Monteiro, T. \& Passos de Carvalho, J. 1984. Lepidópteros do Algarve. Anais da Faculdade de Ciências do Porto 64: 95-219.

Novoa Pérez, J.M., Nieto Manzano, M.A., García-Villanueva, V. \& Moreno Tamurejo, J.A. 2002. Proyecto de muestreo y catalogación de los macroheteróceros de Extremadura, España (Insecta: Lepidoptera). Boletín de la Sociedad Entomológica Aragonesa 30: 121-142.

Parenzan, P. 1998. Osservazioni preliminari sulla Macrolepidopterafauna della reserva naturale di Vendicarì (Siracusa) e prima segnalazione di Leucania palestinae (Staudinger, 1892) (Lepidoptera: Noctuidae) per la fauna italiana. Il Naturalista Siciliano, nuova serie, 22: 355-364.

Parra, L.E. 1995. Lepidoptera, p. 269-279. In: Simonetti, J.A., Arroyo, M.T.K., Spotorno, A.E. \& Lozada, E. (eds.). Biodiversidad Biológica de Chile. Santiago, CONICYT, 364 p.

Pérez Muñoz, P.J. 2007. Análisis del puerto de Valparaíso antes y después del cambio de administración. Senior thesis. Facultad de Ciencias de la Ingenería, Escuela de Ingenería Naval, Universidad Austral de Chile. Available at: www.cybertesis.uach.cl (accessed 9 November 2013).

Pitkin, L.M, Mora, R.A. \& Scoble, M.J. 1996. A checklist of the Ennominae (Geometridae) of Costa Rica: taxonomy for a national biodiversity inventory. Gayana Zoologia 60: 121-155.

Poole, R.W. 1987. A taxonomic revision of the New World moth genus Pero (Lepidoptera: Geometridae). United States Department of Agriculture Technical Bulletin 1698: 1-257.

Prout, L.B. 1935. Brephinae, Oenochrominae, Hemitheinae, Sterrhinae, Larentiinae. In: Seitz, A. (ed.). Die Großschmetterlinge der Erde, supplement 4. Stuttgart, Verlag A. Kernen.

Robinson, G.S. 1976. The preparation of Lepidoptera genitalia with special reference to the Microlepidoptera. Entomologist's Gazette 27: 127-132.

Sanz Alorza, M. 2009. Flora y vegetación arvense y ruderal de la provincia de Huesca. Monografías de Botánica Ibérica. Jaca (Huesca), edited by J. L. Benito Alonso, 677 p. 
Scoble, M.J. 1999. Geometrid Moths of the World:A catalogue (Lepidoptera, Geometridae). vols. 1 \& 2. Collingwood, CSIRO, $1016+129$ p.

Skule, B. 1980. Rhodometra sacraria L. Lidt om artens biologi og udbredelse, samt om den anden europaeiske Rhodometra-art: Rhodometra anthophilaria $\mathrm{Hb}$. Lepidoptera 3: 261-268.

Skule, B. \& Svendsen, P. 1980. Indflyvningen af Rhodometra sacraria L. i Nordeuropa i 1983. Lepidoptera 4: 285-295.

Sparks, T.H., Dennis, R.L.H., Croxton, P.J. \& Cade, M. 2007. Increased migration of Lepidoptera linked to climate change. European Journal of Entomology 104: 139- 143.

Strutzenberger, P., Brehm, G., Bodner, F. \& Fiedler, K. 2010. Molecular phylogeny of Eois (Lepidoptera: Geometridae): evolution of wing patterns and host plant use in a species-rich group of Neotropical moths. Zoologica Scripta 39: 603-620.
Trusch, R. \& Hausmann, A. 2008. A new species of Rhodostrophia Hübner, 1823 from Iran (Geometridae: Sterrhinae). Nota Lepidopterologica 30: 7-16.

Vargas, H.A, Vargas, H.E., Bobadilla, D.E. \& Parra, L.E. 2001. Notas sobre la polilla de la flor del olivo Cyclophora nanaria Walker (Lepidoptera: Geometridae; Sterrhinae). Idesia 19: 25-32.

Vargas, H.A. \& Hausmann, A. 2008. Adiciones a la fauna de geométridos (Lepidoptera: Geometridae) de Chile. Neotropical Entomology 37: 167-168.

Viidalepp, J. 1996. Checklist of the Geometridae (Lepidoptera) of the former USSR. Stenstrup, Apollo Books, $111 \mathrm{p}$.

Viidalepp, J., Maes, J.M. \& Viidalepp, T. 2010. To the knowledge of Geometrid moths of Nicaragua (Lepidoptera: Geometridae). Revista Nicaragüense de Entomología 70 (suppl. 3): 1-69. 